\title{
Concord Communications And Interactions Between Ethnic Groups Supporting The Candidate; Case Study On Paguyuban Suku Tionghoa Indonesia And Joko Tingkir In Election Of Medan City, 2015
}

\author{
Humaizi $^{1}$, Ermansyah ${ }^{2}$, Rudi Salam Sinaga ${ }^{3}$ \\ 1,2 Faculty of social and Political Sciences-University of Sumatera Utara \\ ${ }^{3}$ Students in Doctoral study Program of Social Sciences-University of Diponegoro and Lecturer at the Faculty of social \\ and political sciences of the University of Medan Area \\ Email: humaizi_fisipusu@yahoo.com
}

\begin{abstract}
The ethnic group in Medan city has played an important role to participate in the formation of support groups. The shift from social group concentration to the world of electoral politics gives a new nuance for us to understand the existence of ethnic groups in the life of democracy at the local level which in some cases leads to ethnic conflict in the elections. This study aims to explore the pattern of harmony communication relationships between ethnic groups supporting contestants in the election of regional heads in the city of Medan in 2015. This study used a qualitative approach with descriptive method of case study type. The object of research conducted on two ethnic groups in the city of Medan in the community of the Chinese Tionghoa Indonesia (Paguyuban Suku Tionghoa Indonesia/PASTI) and Joko Tingkir community (Paguyuban Joko Tingkir). Result data through study, library study and documentation. The results of this study review the shift of topics that originally acted in the field of social and then move more broadly into the field of politics in the political practice they apply still uphold the social values contained in the culture of each ethnic through various interactions that promote harmony communications. between ethnic groups through mutual respect.
\end{abstract}

Keywords: Interaction Pattern, Harmony Communication, Ethnic Group, Regional Head Elections

\section{INTRODUCTION}

Located in the city of Medan North Sumatra Province has a heterogeneous population characteristics, with percentage of population based on ethnicity is not too much amount of one ethnic group by another so that no ethnic population so the dominant ethnic group in the city of Medan.

Based on data from the Central Bureau of statistics (BPS) Note There are ethnic Batak, Minang ethnic, ethnic Javanese, Acehnese ethnic Malay, ethnic, ethnic Chinese. Empirically study have many associate the ethnic groups in the context of the establishment of a country because it naturally every human being has a different "identity" with other human beings until each man forming groups that have in common "identity" as contained in the ethnic community groups. Ethnic communities as the basic foundation of the formation of the peoples of the country.

The formation of a nation of diverse ethnic groups that reside in them as citizens not uncommon until the countries have formed nuanced issues of competition still left ethnic groups in competition in the field of Economics and access politics. These situations often end up with conflict. Some of the empirical literature that discusses about ethnic conflicts [1]; [2]; [3]; with political and ethnic groups can read works [4]; [5]; [6] and there are still lots of other literature.
In the context of the city of Medan, characterizing the interactions between ethnic groups still belongs in a life articles though the political dynamics of the elektoral (of the elections) so high with the role of ethnic groups which are involved in providing support political candidates in the elections in the city of Medan.

Interesting to observe the ethnic group which has a low population and high population participated as a support group for the candidate as in the focus of these studies against ethnic Chinese and ethnic Javanese.

Yet there is an accurate data regarding the population numbers of communities of Medan based on ethnicity, but secondary data obtained from the total population of ethnic Chinese in Medan City according to [7] by as much as $11 \%$, based on old data from The Central Bureau of statistics (BPS) of North Sumatra Province in 1980 known as much as $12.8 \%$ and in the year 2000 as much as $10.65 \%$ of the total number of people in the city of Medan totaled 1,904,273 in 2000 and BPS in the year 2015 amount to 2,210,624. While the number of BPS data based on North Sumatra Province the year 2000 the highest ethnic populations respectively occupied by ethnic Javanese as much as 33\%, subsequently followed by ethnic Chinese, ethnic Batak, Minangkabau, Aceh, ethnic Malay in BPS year 2000.

Thus the existence of the ethnic demographic is always a concern in the region, 
especially in political studies political studies elektoral. Previous empirical studies ever examine the question of the ethnic groups in the selection of head region (of the elections) for the study of [8] within the context of the elections of Governors of Jakarta saw even though ethnic groups have an important role in affect the tally of votes in the election but not so significant when compared to the variables of education and the issues that brought in the vision and mission of the candidates. These characteristics as characteristic of the urban area where urban communities more rational political choice in giving. Moreover, the situation is very interesting from the dynamics of support between different ethnic groups do not cause a disruption of the balance of social community in the city of Medan.

Studies that specifically investigated the interaction of ethnic groups can read the work of [9]; [10]; [11]; [12]; [13] and many more. While the study of harmony between ethnic groups can read the works of [14]; [15]; [16] (Haas, 1995); [17] more specific studies and examines the harmony between different ethnic groups in the political elektoral can see works from [18].

This study provides a new perspective in understanding the original ethnic groups of activities in the social dimension and present activities of ethnic groups in the political dimension of the elektoral with the behavior called that remain apply social values applicable in each ethnic group.

A number of ethnic groups in the city of Medan in the real involve the "self" as an ethnic group supporting the candidate head of a region in the election of the head of the area (of the elections), this study takes the case on the election of the head of the Medan area year 2015 where there is the involvement of ethnic groups as a regional head of candidate support groups namely ethnic Chinese associations were Indonesia (Paguyuban Suku Tionghoa Indonesia/PASTI) and Associations Joko Tingkir (Joko Tingkir)

The two ethnic groups with different political options in support to the candidate for head of the areas in the selection of the head of the Medan area the year 2015 in the practice of interaction and communication that they do not cause problems that interfere with harmony between ethnic groups in the period when elections are implemented and after the implementation of the elections. This research will investigate the interaction of internal communication in the ethnic groups which have an impact on the atmosphere of harmony between ethnic groups?

\section{RESEARCH METHODS}

This was a qualitative study using a descriptive approach. The selection of the type of qualitative in this study because of the problems of research can only be answered by using the type of qualitative research because of concerns about the activities and interactions of specific surroundings. In supplementing information and data in this study using interview in-depth study, library and documentation. Informant this research comes from sellers undertakers and Joko Tingkir. Data analysis adopts the model developed by Miles and Huberman.

\section{THEORY FRAMEWORK}

In the study of the politics of the elektoral (of the elections) each candidate is trying to get as many votes in the election. Indicators for achieving that goal one is to build sound support in every element of community groups through the establishment of support groups.

A support group can appear in two ways namely 1) in the form of support groups by candidate or 2) initiative community groups make themselves as a support group. The existence of a support group is not limited to one element of community groups, the more support groups formed and derived from different types of elements of society will be able to influence the sound acquisition candidates in more maximum.

[19] mentions the existence of the influence of the involvement of interest groups against election results. This means for the existence of groups supporting candidates who have an interest against the election outcome (of the elections), so that when a candidate who supported elected elections then they expect the effort to be their interests against candidates elected in the post-war period of the elections.

Groups supporting candidates with ethnic group segmentation in the case of a multiethnic political demographic areas such as Medan city will greatly assist the candidate when the candidate is getting a lot of support from a group of different ethnic groups, this will greatly affect the sound acquisition candidates and potentially be the winner in the elections.

Ethnic groups in a multi-ethnic area in addition to providing great affect against the social system the existence of ethnic groups also serves to influence life in other fields such as economics and politics. This condition will indeed implicates on areas of life given in the ethnic groups stored value or a specific identity as Weber in [20] describes the ethnic identification equation based identity in a wider sense. 
Identity is inherent in the ethnicity form values, symbols and language can be used to achieve other goals in different areas of life according to the will of that ethnic group to bring in what direction they wish to focus. Changes to this orientation according to [21] role in social classification may change and vary in each case.

\section{DISCUSSION}

\section{Concord communications and interaction Internally PASTI}

Communication interactions formed in the territory of the tribe of Indonesia Chinese Association internal (definite) is inseparable from social interaction that stem from China's ethnic culture as civilization explanation [22] ethnic Chinese who settled in East Sumatra using Chinese language to communicate among their fellow. According to [23] every culture has the environmental area. Through interaction with the external environment of the area then new civilizations can appear as any as a result of interactions between different ethnicities form a new civilization with its own environment area. According to [24] interaction can enhance adaptation between ethnic, which in turn raises new civilizations (more advanced) as set forth by [25] is a cultural civilization had advanced. The social construction of society Indonesia has changed, no longer see the ethnic Chinese as in the era of the year 1998 which, according to [26] as the era of the occurrence of anti-Chinese sentiment in Indonesia's largest.

Membership must have come from various professions including the job profession as members of political parties are also divided into the various political parties. This circumstance explains that PASTI put myself as a social-based associations but by no means PASTI break away from the changes that happen in other fields such as economics and politics. But upholding their focus towards social fields as the main objective the creation of certainty. According to Goh Tips Tie (DPW PASTI North Sumatra) explain the identified as organizations who are interested in social issues and are not interested in politics [27].

[27] opinion can be understood to PASTI affirm that the primary purpose is to function as a social organization. Though not able to restrict individual rights each Member surely the personally have professions and different political choices in the political activities of elektoral.

The difference in the political sphere individually between members is PASTI evident where there exists an active PASTI became a member of the party in various political parties such as statement Rianty (Deputy Secretary of DPW PASTI North Sumatera) that Describes the members in organizations there must have been an active member of a political party, and then the same time Goh Tips Tie gives examples such as in DESIGN, and much more [28]

A statement from the administrators PASTI above has a meaning that is PASTI as socialoriented organizations provide social values are positive for the life of the family members but would not be able to limit the personal life of each Member with regard to other things which are guaranteed by legislation in Indonesia. Great value in Chinese culture became the main guidelines for maintaining the balance of harmony in the internal environment of an external group them with the behavior of interactions that upholds the noble values, mutual respect and Please help.

\section{Concord communications and interactions in the Internal Joko Tingkir.}

Behavior inherent in the character strongly influenced in the interweaving of interaction. Communication interactions that are performed by the internal environment of Joko Tingkir organization as a two-way communication process or more that are interactive. Joko Tingkir characters not in spite of the influence of the value inherent in Javanese culture, moreover, Joko Tingkir as an primodialisme community-based organizations community Java then Java culture so strong character inherent in the internal Joko Tingkir organization.

It has become common knowledge in the midst of the community of Medan or even widespread community in Indonesia that Javanese people as a society that is easy to adapt as the value inherent in their culture, known as the concept " nrimo ing pandum "mean Javanese face the reality that must be accepted as a given and not for foxes [29]. The concept of viewpoints in life makes other ethnic perception toward ethnic Javanese ethnic as easily accepted by the new environment.

Interaction of communication used in internal Joko Tingkir political activity in the elections to win a pair of Ramadhan Pohan, Joko Tingkir become more frequent use of oral communication. According to Supiyono as Chairman Joko Tingkir Medan Perjuangan Subdistrict in oral communication is better able to describe the sense of family, while a further written communication describing the pressure. Supiyono further explains the oral communication was used to introduce the couples Ramadhan Pohan amidst internal environment member Joko Tingkir, 
communication in writing, more geared for something that is spreading or notify [30].

A communication interaction in internal harmony Joko Tingkir done by means of oral communication and familiarize interactive so that two-way communication occurs. Advantages of oral communication that is direct and interactive gives the opportunity to the parties involved in communication to be able to verify information directly so very minimal once the confusion in capturing messages from oral communication. Oral communication in view of Joko Tingkir considered more showed the sense of family or fraternity. It embodies a sense of family unity communications can strengthen fraternity against their fellow Moreover the existence of the Java language that also adds to the strong sense of brotherhood in internal Joko Tingkir as the ethnic-based community organizations Java.

\section{CONCLUSION}

Interaction of internal organizational communications group and Joko Tingkir always oriented in their cultural values that serve as the identity to lead in behave and speak the words in the content-positive talk contest like keeping a bad word, not denouncing others and often highlight the mutual help help be it against fellow external surroundings and also against other ethnicities in the external environment.

A good word and spared from denouncing the attitude towards others or different tribes make communication among the ethnic groups of supporters are in a harmonious situation because of the behavior and interactions they do always keep the content Concord communications.

\section{ACKNOWLEDGMENT}

Our gratitude to say the informant research in Chinese Indonesian tribal associations (Paguyuban Suku Tionghoa Indonesia/PASTI) and Joko Tingkir associations (Paguyuban Joko Tingkir). We pass on a thank you to the Research Institute of Sumatera Utara University and the Faculty of social science and political science University of Sumatera Utara

\section{REFERENCE}

[1] Jacob, R. I. (2014). Ethnic Conflict between the Muslims and Christians in Nigeria: The Dilemma of Decision-Making of the Political Elites. International Journal of Multicultural and Multireligious Understanding (IJMMU), 1(1), 1-11.

[2] Warren, T. C., \& Troy, K. K. (2015). Explaining Violent Intra-Ethnic Conflict. Journal of
Conflict Resolution, 59(3), 484-509.

http://doi.org/10.1177/0022002713515400

[3] Cunningham, K. G., \& Weidmann, N. B. (2010). Shared Space: Ethnic Groups, State Accommodation, and Localized Conflict. International Studies Quarterly, 54(4), 10351054. http://doi.org/10.1111/j.1468-

2478.2010.00625.x

[4] Kanalan, E., \& Celep, C. (2011). A glance to education in the middle east under the shadow of politic and ethnic conflicts in the region. In Procedia - Social and Behavioral Sciences (Vol. 15, pp. 2864-2868). http://doi.org/10.1016/j.sbspro.2011.04.204.

[5] Ordeshook, P. C., \& Shvetsova, O. V. (1994). Ethnic Heterogeneity, District Magnitude, and the Number of Parties Author. American Journal of Political Science, 38(1), 100-123. http://doi.org/10.2307/2111337.

[6] Sorens, J. (2010). The politics and economics of official ethnic discrimination: A global statistical analysis, 1950-2003. International Studies Quarterly, 54(2), 535-560. http://doi.org/10.1111/j.14682478.2010.00598.x

[7] Suryadinata, Leo, 2010. Etnis Tionghoa dan Nasionalisme Indonesia, (Jakarta: Kompas, 2010), hal. 5.

[8] Prasetyawan, W. (2014). Ethnicity and Voting Patterns in the 2007 and 2012 Gubernatorial Elections in Jakarta. Journal of Current Southeast Asian Affairs, 33(1), 29-54. Retrieved from http://scholar.google.com/scholar?hl=en\&btnG= Search\&q=intitle:Ethnicity+and+Voting+Pattern s+in+the+2007+and+2012+Gubernatorial+Elect ions+in+Jakarta\#0

[9] Phinney, J. S., Horenczyk, G., Liebkind, K., \& Vedder, P. (2001). Ethnic identity, immigration, and well-being: An interactional perspective. Journal of Social Issues, 57(3), 493-510. http://doi.org/10.1111/0022-4537.00225

[10] Ahmad, Y., \& Yusof, N. M. (2010). Ethnic boundary among students in Malaysian primary schools and social interaction: A conceptual framework. In Procedia - Social and Behavioral Sciences (Vol. 7, pp. 82-91). http://doi.org/10.1016/j.sbspro.2010.10.013 
[11] Kim-ju, G. M., \& Liem, R. (2003). Ethnic selfawareness as a function of ethnic group status, group composition, and ethnic identity orientation. Cultural Diversity \& Ethnic Minority Psychology, 9(3), 289-302. http://doi.org/10.1037/1099-9809.9.3.289

[12] Husband, C. (2005). Minority ethnic media as communities of practice: Professionalism and identity politics in interaction. Journal of Ethnic and Migration Studies, 31(3), 461-479. http://doi.org/10.1080/13691830500058802

[13] Stone, T. (2003). Social Identity and Ethnic Interaction in the Western Pueblos of the American Southwest. Journal of Archaeological Method and Theory, 10(1), 31-67. http://doi.org/10.2307/20177472

[14] Baidhawy, Z. (2007). Building harmony and peace through multiculturalist theology-based religious education: An alternative for contemporary Indonesia. British Journal of Religious Education, 29(1), 15-30. http://doi.org/10.1080/01416200601037478

[15] Massey, G., Hodson, R., Sekulić, D., \& Sekulic, D. (1999). Ethnic Enclaves and Intolerance: The Case of Yugoslavia. Social Forces, 78(2), 669693. http://doi.org/10.1093/sf/78.2.669

[16] Haas, M. (1995). Alternative Theories of Ethnic Harmony. Southeastern Political Review, 23(2), 261-280. http://doi.org/10.1111/j.17471346.1995.tb00413.x

[17] Jakupov, S. M., Perlenbetov, M. A., Ilimkhanova, L. S., \& Telebayev, G. T. (2012). Cultural Values as an Indicator of Inter-Ethnic Harmony in Multicultural Societies. Procedia Social and Behavioral Sciences, 69, 114-123. http://doi.org/10.1016/j.sbspro.2012.11.390

[18] Case, W. (2013). Post-GE13: Any Closer to Ethnic Harmony and Democratic Change? Round Table, 102(6), 511-519. http://doi.org/10.1080/00358533.2013.857147

[19]Panagopoulos, C., 2006. Vested Interests : Interest Group Resource Allocation in Presidential Campaigns. Journal of Political Marketing, 5(1-2), pp.59-78.

[20] Strijbis, O. \& Kotnarowski, M., 2015. Measuring the electoral mobilization of ethnic parties: Towards comparable indicators. Party Politics, 21(3), pp.456-469.
[21] Yang, B., 2009. Central State, Local Governments, Ethnic Groups and the Minzu Identification in Yunnan (1950s-1980s). Modern Asian Studies, 43(3), pp.742.

[22] Vleming Jr,J.I, 1989. Kongsi dan Spekulasi, Jaringan Kerja Bisnis Tionghoa, Jakarta: Pustaka Utama Graffiti.pp.185

[23] Cohen, A.Y., 1970. Schools and Civilizational States, dalam The Social Sciences and The Comparative Study of Education systems. (Joseph Fischer; editor). Pennsylvania: International Textbook Company.pp.64

[24]Taum, Y.Y, 2006. Masalah-Masalah Sosial Dalam Masyarakat Multietnik, Papers in the focus group discussion "Identifikasi Isu-Isu Strategis yang Berkaitan dengan pembangunan karakter dan pekerti bangsa, Balai Kajian Sejarah dan nilai tradisional Yogyakarta. Yogyakarta.pp.5

[25] Pidarta, M., 1997. Landasan Pendidikan: Stimulus Ilmu Pendidikan Bercorak Indonesia. Jakarta : Rineka Cipta.pp.158

[26] Adi, Yustia Atsanatrilova, Potret Pribumi Dalam Kontruksi Sosial Warga Etnis Tionghoa Surakarta Pasca Kerusuhan Mei 1998. Tesis, Pascasarjana Sosiologi, Universitas Gadjah Mada.pp. 1

[27] Goh Kiat Tie, Ketua DPW PASTI Provinsi Sumatera Utara, Interview, 2017.

\section{[28] Rianty, S.H., Wakil Sekjen DPW PASTI} Provinsi Sumatera Utara, Interview, 2017

[29] Susatyo, R, 2008. Seni dan Budaya Politik Jawa, Bandung: Koperasi Ilmu Pengetahuan Sosial.pp.47.

[30] Supiyono, Ketua Joko Tingkir di Kecamatan Medan Perjuangan, Interview, 2017 